\title{
Geographic, bathymetric and inter-annual variability in the distribution of Liocarcinus depurator (Brachyura: Portunidae) along the Mediterranean coast of the Iberian Peninsula*
}

\author{
MARTA M. RUFINO ${ }^{1,2}$, PERE ABELLÓ ${ }^{2}$, ANDREW B. YULE ${ }^{3}$ and PEDRO TORRES ${ }^{4}$ \\ ${ }^{1}$ CripSul, Ipimar/Iniap, Av. 5 Outubro, s/n 8700-305 Olhão, Portugal. E-mail: mrufino@ cripsul.ipimar.pt \\ ${ }^{2}$ Institut de Ciències del Mar (CSIC), Passeig Marítim de la Barceloneta 37-49, 08003 Barcelona, Spain. \\ ${ }^{3}$ School of Ocean Sciences, University of Wales - Bangor, UK. \\ ${ }^{4}$ Instituto Español de Oceanografia, Centro Oceanográfico de Málaga, Spain.
}

\begin{abstract}
SUMMARY: The patterns of occurrence and density of Liocarcinus depurator along the western Mediterranean coast (from Gibraltar to Cape Creus) were measured at depths between 25 and $800 \mathrm{~m}$. Bottom trawl surveys were carried out from 1994 to 2003. For analysis, the area was divided into eight geographic sectors and eight depth intervals. The highest crab occurrences $\left(\sim 80 \%\right.$ of trawls) and densities $\left(985 \mathrm{crabs} \mathrm{km}^{-2}\right.$ on average) were found on the shallow muddy continental shelf at depths of 51-100 m with the next highest densities on the upper slope between 201 and $300 \mathrm{~m}$ depth $\left(\sim 130 \mathrm{crabs} \mathrm{km}^{-2} \mathrm{on}\right.$ average) and occurrence (66\% of trawls) between 301 and $400 \mathrm{~m}$. Below $500 \mathrm{~m}$, both crab occurrence and density dropped sharply and L. depurator occurred in less than $10 \%$ of all trawls. Thus $L$. depurator appears to slightly avoid areas on the continental shelf break which are characterised by coarser sediments than on the adjacent continental shelf and slope. Geographically, maximum crab occurrence and density were observed off Valencia $\left(86 \%, 1187 \mathrm{crabs} \mathrm{km}^{-2}\right)$ and West Alborán $\left(83 \%, 974 \mathrm{crabs} \mathrm{km}^{-2}\right)$, followed by the Ebro Delta $\left(75 \%, 502 \mathrm{crabs} \mathrm{km}^{-2}\right)$. Off Alicante L. depurator were relatively common ( $74 \%$ of trawls) but at lower densities ( $294 \mathrm{crabs} \mathrm{km}^{-2}$ on average). Abundance off the coast of North Catalonia (317 crabs $\mathrm{km}^{-2}$ ) was equivalent to that off Alicante but the crabs were generally less common (53\% of trawls). In general, the highest densities of $L$. depurator occurred in areas with a wide continental shelf and muddy sediments. During the ten years from 1994 to 2003, densities decreased at a rate of 8 and $4 \%$ per annum in shallower water and water deeper than $150 \mathrm{~m}$ respectively with a similar decrease in percentage occurrence. This pattern is discussed in relation to the physiological tolerance of the species and reported trends of warming in the Mediterranean Sea.
\end{abstract}

Keywords: Liocarcinus depurator, annual variation, bathymetric, geographic, western Mediterranean, densities, occurrence.

RESUMEN: VARIABILIDAD GEOGRÁFICA, BATIMÉTRICA E INTERANUAL EN LA DISTRIBUCIÓN DE LIOCARCINUS DEPURATOR (BRACHYURA: PORTUNIDAE) A LO LARGO DE LA COSTA MEDITERRÁNEA DE LA PENÍNSUlA IBÉRICA. - Las pautas de presencia y densidad de Liocarcinus depurator a lo largo de la costa mediterránea occidental (desde Gibraltar a Cabo Creus) se han estudiado a profundidades comprendidas entre 25 y $800 \mathrm{~m}$. Se realizaron campañas anuales de arrastre demersal desde 1994 a 2003. Para su análisis el área se dividió en 8 sectores geográficos y 8 intervalos de profundidad. El mayor número de presencias de la especie ( $\sim 80 \%$ de las pescas) y las mayores densidades (985 individuos $\mathrm{km}^{-2}$ de media) se hallaron en fondos de fango de la plataforma continental somera en el intervalo de profundidad de 51-100 m, mostrando otro pico de densidades altas, pero no tan elevadas, en el talud continental superior en el intervalo de profundidad de 201-300 m ( 130 individuos $\mathrm{km}^{-2}$ de media), así como de presencias (66\% de las pescas) en el intervalo de 301-400 m. A profundidades superiores a $500 \mathrm{~m}$, tanto las presencias como las densidades disminuyen abruptamente y L. depurator estuvo presente en menos del $10 \%$ de las pescas realizadas. Así, L. depurator parece evitar en cierta medida el límite plataforma-talud, caracterizado por la presencia de sedimentos más arenosos, no tan fangosos como en las áreas adyacentes de la plataforma y talud continentales. Geográficamente, los mayores valores de presencia y densidad se observaron en el sector de Valencia (86\%, 1187 indi-

*Received March 23, 2005. Accepted July 22, 2005. 
viduos $\mathrm{km}^{-2}$ ) y Alborán Oeste $\left(83 \%, 974\right.$ individuos $\left.\mathrm{km}^{-2}\right)$, seguido por el sector delta del Ebro $\left(75 \%, 502\right.$ individuos $\left.\mathrm{km}^{-2}\right)$. En el sector de Alicante L. depurator fue relativamente común (74\% de las pescas) pero a densidades menores (294 individuos $\mathrm{km}^{-2}$ de media). La abundancia en el sector Catalunya Norte (317 individuos $\mathrm{km}^{-2}$ ) fue equivalente a la del sector Alicante, pero las presencias fueron menores (53\% de las pescas). En general, las mayores densidades de L. depurator se encontraron en areas con una plataforma continental ancha y sedimentos fangosos. A lo largo de los 10 años de muestreo entre 1994 y 2003, las densidades decrecieron a una tasa comprendida entre 8 y 4\% por año respectivamente en profundidades inferiores y superiores a $150 \mathrm{~m}$, hallándose también una disminución similar en el porcentaje de presencias. Estas pautas se discuten en relación a la tolerancia fisiológica de la especie y a las tendencias de calentamiento del agua marina reportadas para el Mar Mediterráneo.

Palabras clave: Liocarcinus depurator, variación anual, batimétrica, geográfica, Mediterráneo occidental, densidades, ocurrencia.

\section{INTRODUCTION}

Studying the biology and detailed spatial distribution of key species within ecosystems, even if they do not constitute a specific target of the fishery, must be a fundamental step towards understanding the impact and consequences of fishing within an ecosystem and hence a step towards an efficient management strategy. The Mediterranean Sea is characterised by spatial heterogeneity and multispecific fisheries. Since demersal trawls are relatively unselective, trawl surveys can provide information not only on target species, but also on potentially key members of benthic communities. In this way, lengthy time series of trawl surveys are rare but are clearly essential for assessing the impact of natural and anthropogenic changes in benthic communities (Beare et al., 2004, 2005).

Liocarcinus depurator (Linnaeus, 1758) is a portunid crab common on the continental shelf and upper slope of the north-east Atlantic and Mediterranean Sea (Mori and Zunino, 1987; Abelló et al., 1988; González-Gurriarán et al., 1993; Ungaro et al., 1999). It ranges in distribution from the coasts of the western Sahara to Norway, including the Mediterranean (d'Udekem d'Acoz, 1999), where it is one of the most abundant members of continental shelf communities (Ungaro et al., 1999; Abelló et al., 2002). As a major predator within its community (Abelló and Cartes, 1987; Mori and Manconi, 1989; Hall et al., 1990; Freire, 1996), L. depurator probably occupies a central role in developing and maintaining community structure in many continental shelf faunal assemblages. Studying variability and change in L. depurator distribution patterns provides useful information for understanding its population dynamics and its importance to continental shelf community ecology.

The aim of the present work is to analyse the occurrence and density of L. depurator throughout a ten year series of standardised trawl surveys (Bertrand et al., 2000, 2002) performed along the Mediterranean coast of the Iberian Peninsula.

\section{MATERIAL AND METHODS}

\section{Survey details}

The study area encompassed the Mediterranean coast of the Iberian Peninsula, from Gibraltar to Cape Creus (Fig. 1). A bottom trawl survey was performed annually from 1994 to 2003 (Bertrand et al., 2002). Survey stations were chosen by stratified random sampling with strata delineated by depth and geography. Details of the survey strategy, part of the

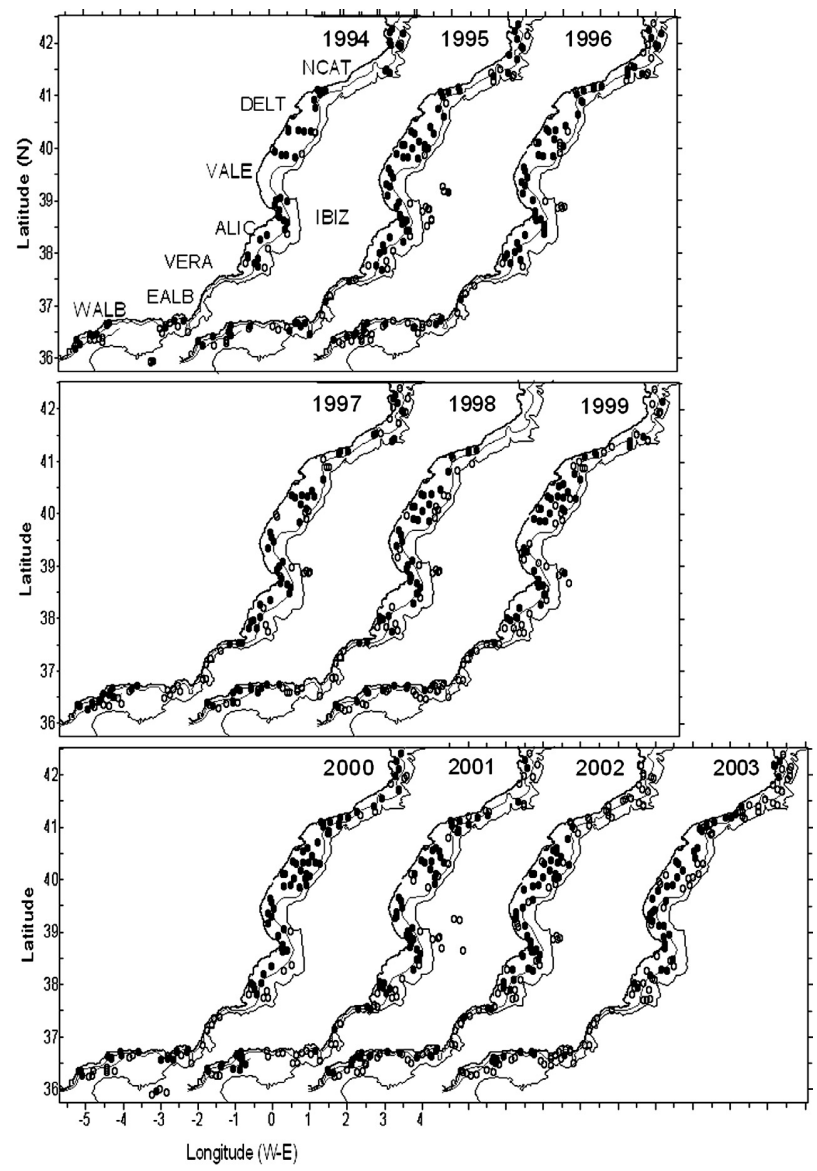

FIG. 1. - The position of trawls showing the presence (black circles) and the absence (empty circles) of Liocarcinus depurator in trawls throughout the study area from 1994 to 2003 . The longitude scale refers directly to 1994,1997 and 2000 outlines only. Contour lines represent depths of 200 and $1000 \mathrm{~m}$. 
TABLE 1. - Number of hauls performed in each geographic area and depth interval. WALB: Western Alborán Sea, EALB: Eastern Alborán Sea, VERA: Gulf of Vera, ALIC: Alicante, IBIZ: Ibiza island, VALE: Valencia, DELT: Ebro Delta region, NCAT: North Catalonia.

\begin{tabular}{|c|c|c|c|c|c|c|c|c|c|}
\hline Depth (m) & WALB & EALB & VERA & ALIC & IBIZ & VALE & DELT & NCAT & Total \\
\hline $25-50$ & 13 & 9 & 3 & 20 & - & 8 & 33 & 17 & 103 \\
\hline $51-100$ & 33 & 22 & 11 & 55 & - & 50 & 118 & 53 & 342 \\
\hline $101-150$ & 13 & 8 & 5 & 23 & 3 & 23 & 29 & 50 & 154 \\
\hline $151-200$ & 9 & 5 & 8 & 17 & - & 3 & 4 & 9 & 55 \\
\hline $201-300$ & 13 & 9 & 13 & 13 & 8 & 2 & 1 & 15 & 74 \\
\hline $301-400$ & 23 & 12 & 5 & 12 & 2 & 7 & 1 & 18 & 80 \\
\hline $401-500$ & 8 & 12 & 5 & 22 & 8 & - & 2 & 23 & 80 \\
\hline $501-600$ & 20 & 17 & 7 & 24 & 9 & 1 & - & 23 & 101 \\
\hline $601-700$ & 27 & 15 & 2 & 2 & 6 & - & - & 18 & 70 \\
\hline $701-800$ & 18 & 3 & 6 & & 2 & 8 & - & 2 & 39 \\
\hline Total & 177 & 112 & 65 & 188 & 38 & 102 & 188 & 228 & 1098 \\
\hline
\end{tabular}

much larger MEDITS program encompassing all European Mediterranean waters, can be found in Bertrand et al. (2002).

Trawls were taken at $50 \mathrm{~m}$ depth intervals down to $200 \mathrm{~m}$, and $100 \mathrm{~m}$ intervals on the continental slope (Abelló et al., 2002). Although Bertrand et al. (2002) only defined three broad geographical sectors for the whole study area, the high sampling density allowed smaller areas to be defined based on the different geomorphic and hydrographic characteristics. Again, following Abelló et al. (2002), the coast was partitioned into eight geographical sectors or regions (Fig. 1): (1) the Western Alborán Sea (WALB), from Gibraltar to Nerja; (2) the Eastern Alborán Sea, from Nerja to Cape Gata; (3) the Gulf of Vera (VERA), from Cape Gata to Cape Palos; (4) Alicante (ALIC), from Cape Palos to Cape La Nao; (5) Ibiza island (IBIZ); (6) Valencia (VALE), from Cape La Nao to Castelló; (7) the Ebro Delta region (DELT), from Castelló to Tarragona and (8) North Catalonia (NCAT), from Tarragona to Cape Creus. Table 1 shows the number of hauls performed in each geographic area and depth interval.

The sampling gear used throughout (GOC 73; Fiorentini et al., 1999) was designed for sampling a wider range of organisms than most commercial trawls by having a smaller mesh (codend mesh size: $20 \mathrm{~mm}$ stretched mesh) and a narrower, higher opening of 2.5 to $3 \mathrm{~m}$ height. Hauls taken at depths shallower than $200 \mathrm{~m}$ lasted 30 minutes, whereas the deeper trawls lasted 60 minutes. All L. depurator individuals in each haul were counted, weighed with an electronic balance adapted to vessel motion, and the carapace width in $\mathrm{mm}$ (to $0.1 \mathrm{~mm}$ ) measured immediately after capture. Density was then standardised to swept area (number $\mathrm{km}^{-2}$ ) based on the horizontal opening of the net (obtained from a net fitted Scanmar), distance trawled (estimated from
GPS readings) and assuming $100 \%$ capture efficiency. From 1994 to 2003, a total of 1098 hauls were performed in an overall area of $45331 \mathrm{~km}^{2}$ off the Mediterranean coast of the Iberian Peninsula. Figure 1 shows the distribution of the 77 to 135 hauls taken each year. The Ibiza and Alborán Island (in the south of the East Alborán sector) areas were not sampled every year and thus were excluded from the analysis. Furthermore, the northern part of the North Catalonia sector could not be sampled in 1998 . Whenever possible, the same stations were sampled each year. The number of hauls in each area varied with the width of the continental shelf. Thus, the Gulf of Vera was sampled less intensively owing to the steepness of the continental shelf and slope, whereas the Ebro Delta sector was sampled more intensively because of its wide continental shelf.

Table 2 shows that sampling took place from the end of April through to June, with minor annual differences. Thus, surveys in 1994 and 2000 ended on 19 and 23 June respectively and those in 1995 and 2003 ended on 21 and 26 May respectively. The earliest start and the latest finish dates for the surveys were 22 April (1995) to 23 June (2000), a period of two months.

TABLE 2. - Start and end dates and depth range sampled in each year of the survey.

\begin{tabular}{lcccc}
\hline & \multicolumn{2}{c}{ date } & \multicolumn{2}{c}{ Depth $(\mathrm{m})$} \\
year & start & end & $\min$ & $\max$ \\
& & & 27 & 786 \\
1994 & $28 / 05 / 94$ & $19 / 06 / 94$ & 25 & 771 \\
1995 & $22 / 04 / 95$ & $21 / 05 / 95$ & 27 & 780 \\
1996 & $02 / 05 / 96$ & $27 / 05 / 96$ & 27 & 761 \\
1997 & $10 / 05 / 97$ & $03 / 06 / 97$ & 25 & 727 \\
1998 & $03 / 05 / 98$ & $30 / 05 / 98$ & 27 & 790 \\
1999 & $04 / 05 / 99$ & $03 / 06 / 99$ & 31 & 776 \\
2000 & $22 / 05 / 00$ & $23 / 06 / 00$ & 31 & 796 \\
2001 & $12 / 05 / 01$ & $14 / 06 / 01$ & 27 & 760 \\
2002 & $11 / 05 / 02$ & $13 / 06 / 02$ & 30 & 792 \\
2003 & $26 / 04 / 03$ & $26 / 05 / 03$ & & \\
\hline
\end{tabular}


TABlE 3. - Percentage occurrence (number of hauls with Liocarcinus depurator as a percentage of all hauls taken) in each geographic area and depth interval throughout the Mediterranean coast of the Iberian Peninsula.

\begin{tabular}{|c|c|c|c|c|c|c|c|c|c|}
\hline Depth/sector & WALB & EALB & VERA & ALIC & IBIZ & VALE & DELT & NCAT & Total \\
\hline $25-50$ & 76.9 & 0 & 33.3 & 55.0 & - & 37.5 & 66.7 & 64.7 & 56.3 \\
\hline $51-100$ & 90.9 & 31.8 & 63.6 & 81.8 & - & 92.0 & 83.9 & 71.7 & 79.5 \\
\hline $101-150$ & 84.6 & 37.5 & 40.0 & 91.3 & 0 & 95.7 & 51.7 & 48.0 & 63.6 \\
\hline $151-200$ & 100 & 60.0 & 50.0 & 64.7 & - & 33.3 & 0 & 22.2 & 54.5 \\
\hline $201-300$ & 100 & 66.7 & 23.1 & 76.9 & 0 & 100 & 100 & 46.7 & 56.8 \\
\hline $301-400$ & 69.6 & 58.3 & 0 & 100 & 50.0 & 85.7 & 100 & 55.6 & 66.3 \\
\hline $401-500$ & 50.0 & 50.0 & 0 & 40.9 & 12.5 & - & 100 & 30.4 & 36.3 \\
\hline $501-600$ & 5.0 & 5.9 & 0 & 4.2 & 0 & 0 & - & 21.7 & 7.9 \\
\hline $601-700$ & 14.8 & 0 & 0 & 0 & 0 & - & - & 5.6 & 7.1 \\
\hline $701-800$ & 5.6 & 0 & 0 & - & 0 & 12.5 & - & 5.0 & 7.7 \\
\hline All depths & 55.9 & 29.5 & 26.2 & 63.8 & 5.3 & 79.4 & 74.5 & 46.5 & 54.5 \\
\hline Depths $<500 \mathrm{~m}$ & 83.0 & 41.6 & 34.0 & 73.5 & 9.5 & 86.0 & 74.5 & 53.5 & 65.5 \\
\hline
\end{tabular}

\section{RESULTS}

\section{Occurrences}

The percentage occurrence of $L$. depurator at each depth interval and geographic area (Table 3) shows that $L$. depurator occurred throughout the surveyed area. Figure 1, however, shows that in certain regions, the Ebro Delta for example, crabs were consistently found each year whereas in other areas, e.g. the northern part of North Catalonia, L. depurator occurrences decreased markedly towards the end of the sampling period.

L. depurator occurred at all sampled depths (but not all depths in all areas), although its greatest percentage occurrence $(\sim 80 \%)$ was between 51 and 100 m. A second peak in occurrences was observed between 151 and $400 \mathrm{~m}$, where crabs appeared in 55 to $66 \%$ of all hauls. The percentage occurrence dropped sharply below $500 \mathrm{~m}$ (7-8\% of all hauls). Trawls deeper than $500 \mathrm{~m}$ were therefore excluded from further analysis. Figure 2 shows the percentage

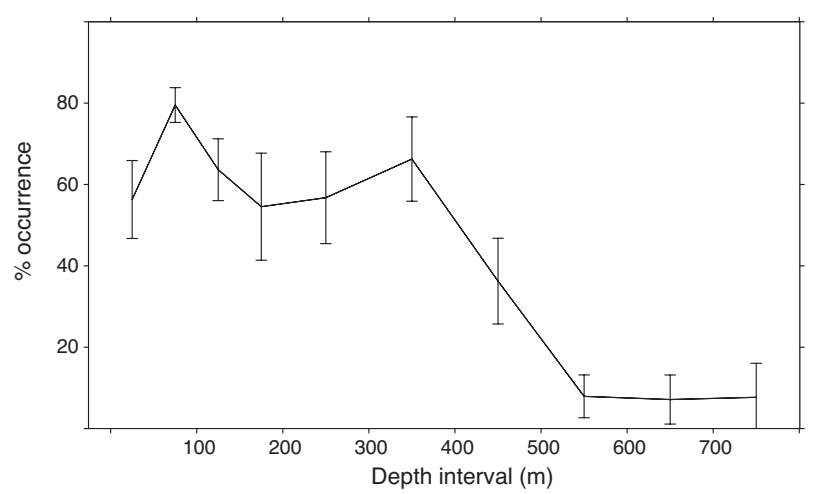

FIG. 2. - Percentage occurrence of Liocarcinus depurator $\left( \pm \mathrm{CI}_{95 \%}\right)$ with depth along the Mediterranean coast of the Iberian Peninsula from 1994 to 2003 (entire geographic range and all years staked). occurrence ( \pm binomial $\mathrm{CI}_{95 \%}$ ) of $L$. depurator with depth across all regions and sampled years. The occurrence showed a very consistent percentage of $55-66 \%$, with considerable overlap in $\mathrm{CI}_{95 \%}$, over the depth range $25-400 \mathrm{~m}$. The small $\mathrm{CI}$ at $51-100 \mathrm{~m}$ results from the intensive sampling at these depths (342 out of 1098 tows, see Table 1). The distribution with depth was distinctly bimodal with one peak at 51-100 m and a smaller one at 301-400 m. Occurrence then dropped sharply over the next $200 \mathrm{~m}$ with only 16 out of 210 trawls yielding L. depurator below $500 \mathrm{~m}$.

\section{Geographical variability}

The geographical sectors of Valencia, West Alborán, the Ebro Delta and Alicante had the highest percentage occurrence of $L$. depurator, ranging between 74 and $86 \%$ at depths $<500 \mathrm{~m}$ (Table 3). At Vera and East Alborán, occurrences ranged only between 34 and $42 \%$ and $54 \%$ in North Catalonia. Around the Island of Ibiza, L. depurator occurred in less than $10 \%$ of trawls, even in shallow waters.

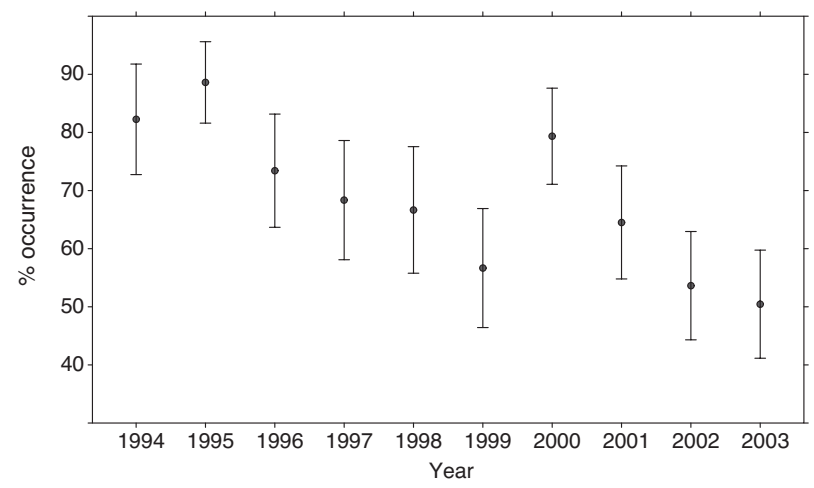

FIG. 3. - The percentage of hauls in which Liocarcinus depurator occurred $\left( \pm \mathrm{CI}_{95 \%}\right)$ at depths shallower than $500 \mathrm{~m}$, along the Mediterranean coast of the Iberian Peninsula, from 1994 to 2003. 
TABLE 4. - Percentage occurrence of Liocarcinus depurator in waters less than $500 \mathrm{~m}$ depth along the Mediterranean coast of the Iberian Peninsula from 1994 to 2003.

\begin{tabular}{|c|c|c|c|c|c|c|c|c|c|c|}
\hline & 1994 & 1995 & 1996 & 1997 & 1998 & 1999 & 2000 & 2001 & 2002 & 2003 \\
\hline Total hauls & 77 & 106 & 105 & 100 & 92 & 116 & 111 & 122 & 134 & 135 \\
\hline Total hauls $(<500 \mathrm{~m})$ & 62 & 84 & 81 & 81 & 74 & 92 & 92 & 99 & 112 & 111 \\
\hline Total hauls with $L$. depurator & 53 & 72 & 62 & 55 & 50 & 54 & 73 & 64 & 59 & 56 \\
\hline Hauls with $L$. depurator at $<500 \mathrm{~m}$ & 51 & 71 & 58 & 54 & 48 & 52 & 73 & 60 & 59 & 56 \\
\hline$\%$ hauls with $L$. depurator at $<500 \mathrm{~m}$ & 82.3 & 84.5 & 71.6 & 66.7 & 64.9 & 56.5 & 79.3 & 60.6 & 52.7 & 50.5 \\
\hline
\end{tabular}

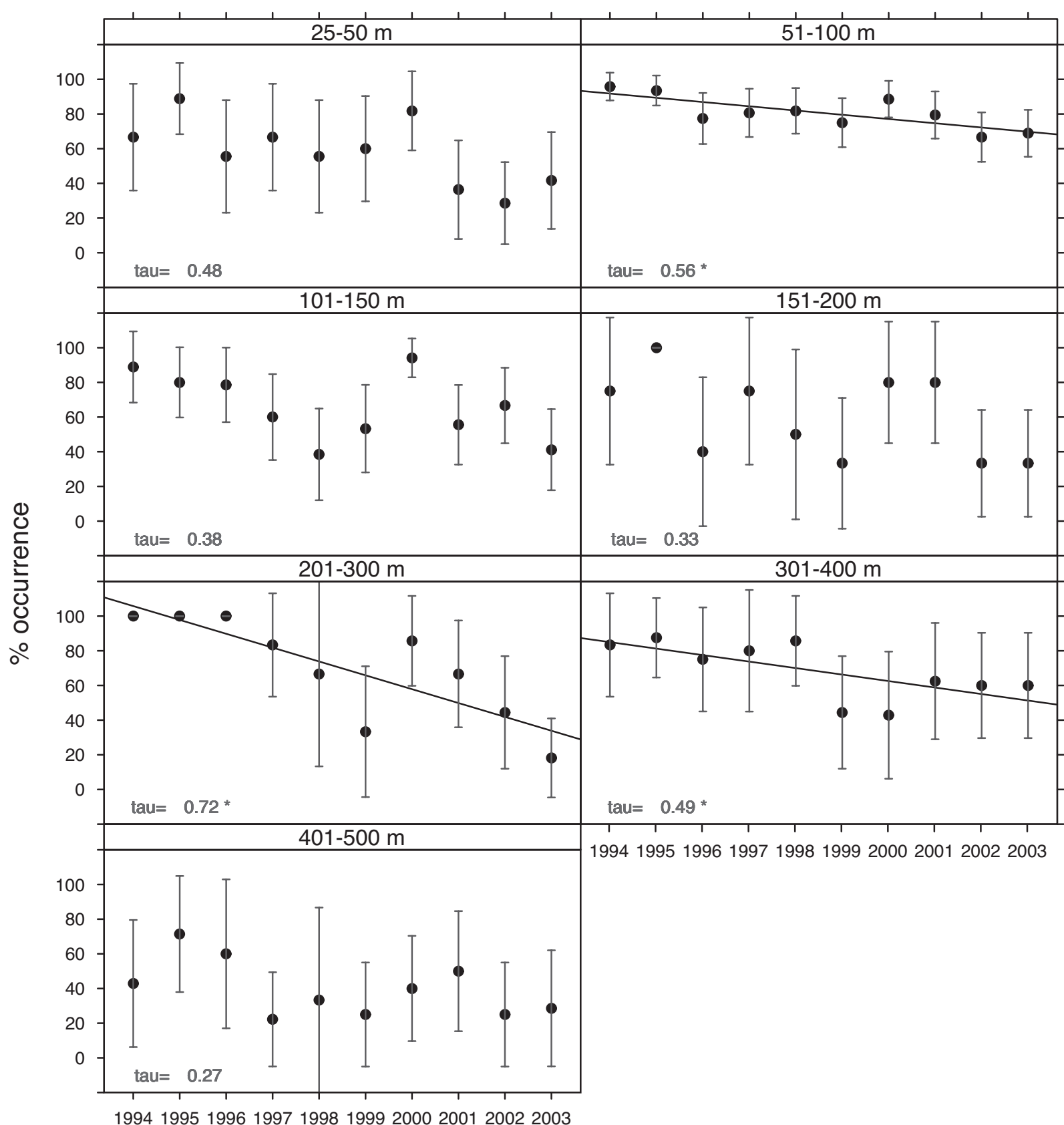

Year

FIG. 4. - Annual variation of the percentage occurrence $\left( \pm \mathrm{CI}_{95 \%}\right)$ of Liocarcinus depurator grouped into depth intervals. The value of Kendal's $\mathrm{T}$ is indicated in the bottom left corner of each figure, followed by an * when significant. Lines fitted to significant relationships by least squares regression are merely indicative of the trend. 


\section{Interannual variability}

Table 4 summarises the occurrences of L. depurator along the Mediterranean coast of Spain during the 10 year series from 1994 to 2003. The number of valid hauls taken steadily increased over the ten years from a low 77 in 1994 to a high 135 in 2003 . Figure 3 shows the percentage occurrence $\left( \pm \mathrm{CI}_{95 \%}\right.$, binomial $)$ at depths shallower than $500 \mathrm{~m}$, averaged across the geographic areas. There is a clear decreasing trend in occurrence (Kendal's $\mathrm{T}=-0.73, \mathrm{~T}=6, \mathrm{p}=0.002$ ), indicating an average decrease of $\sim 3.5 \%$ per year. Superimposed on the general trend are two peaks in occurrence followed by a decreasing trend in the following years. These are evident from 1995 to 1999 and 2000 to 2003. The average rate of decrease during these two periods was $\sim 8 \%$ per year, more than double that of the general trend. During 2003, the year with the highest sampling effort, $L$. depurator occurrence reached its lowest annual level (51\%).

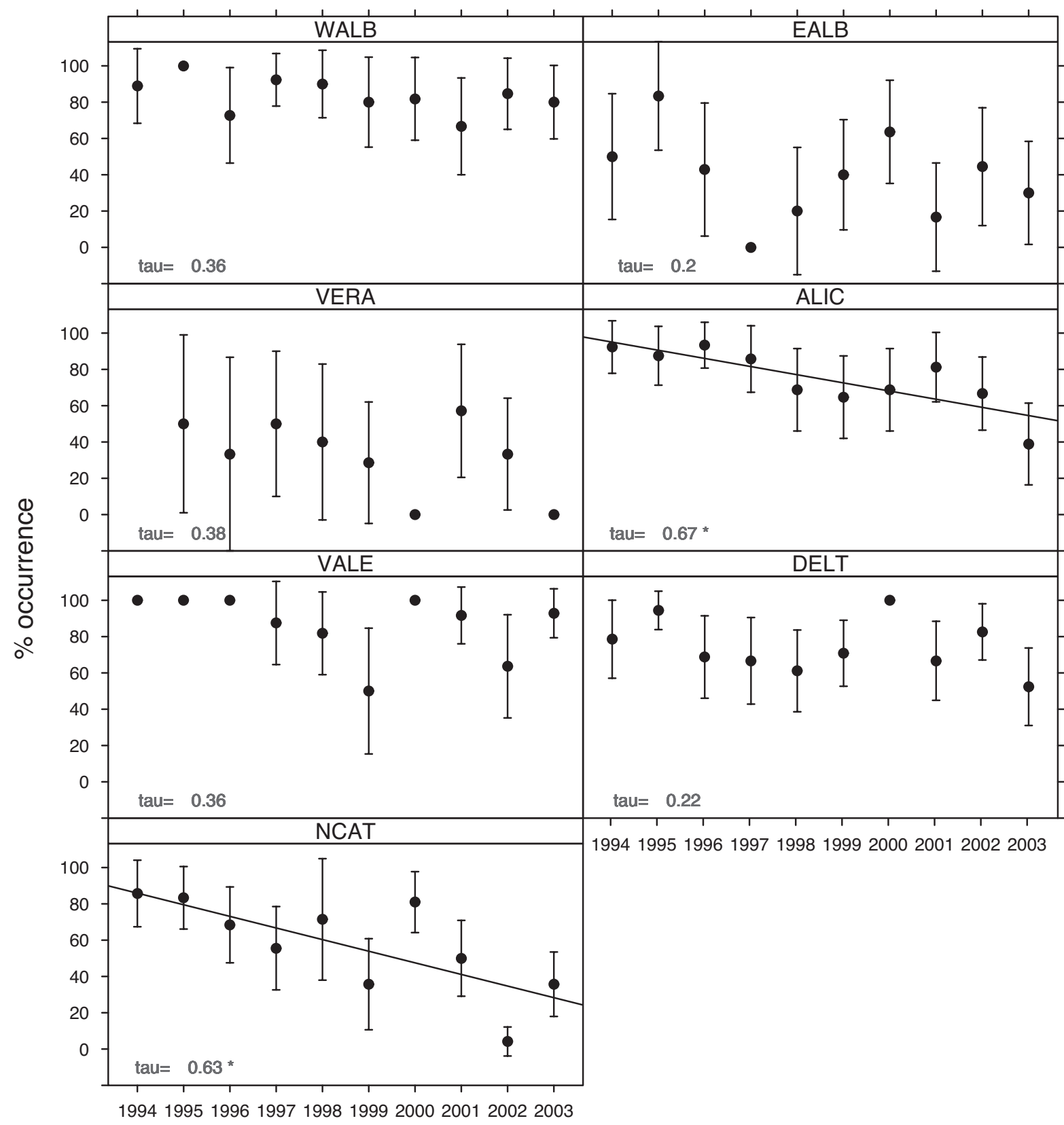

Year

FIG. 5. - Annual and geographic variation of the percentage occurrence $\left( \pm \mathrm{CI}_{95 \%}\right)$ of Liocarcinus depurator. The value of Kendal's T is indicated in the bottom left corner of each figure, followed by an $*$ when significant. Lines fitted to significant relationships by least squares regression are merely indicative of the trend. 
TABLE 5. - Mean density (number $\mathrm{km}^{-2}$ ) of Liocarcinus depurator in each geographic area and depth interval, throughout the Mediterranean coast of the Iberian Peninsula.

\begin{tabular}{|c|c|c|c|c|c|c|c|c|c|}
\hline Depth (m) & WALB & EALB & VERA & ALIC & IBIZ & VALE & DELT & NCAT & Total \\
\hline $25-50$ & 633 & 0 & 44 & 88 & - & 24 & 553 & 195 & 310 \\
\hline $51-100$ & 2677 & 96 & 265 & 543 & - & 1881 & 620 & 873 & 985 \\
\hline $101-150$ & 195 & 102 & 21 & 327 & 0 & 600 & 91 & 130 & 220 \\
\hline $151-200$ & 223 & 17 & 108 & 180 & - & 7 & 0 & 39 & 116 \\
\hline $201-300$ & 307 & 206 & 14 & 139 & 0 & 602 & 29 & 35 & 130 \\
\hline $301-400$ & 135 & 41 & 0 & 256 & 6 & 155 & 93 & 53 & 110 \\
\hline $401-500$ & 106 & 25 & 0 & 23 & 2 & - & 105 & 35 & 33 \\
\hline Depths $<500 \mathrm{~m}$ & 974 & 73 & 84 & 294 & 2 & 1187 & 502 & 317 & 484 \\
\hline
\end{tabular}

Figure 4 shows that there was no consistent pattern for the changes in L. depurator occurrence over the 10 years of the survey within any depth range. Significant negative correlations were observed at 51-100 m, 201-300 m and 301-400 m. However, given the overlap in $\mathrm{CI}_{95 \%}$, even these significant correlations show inconsistent annual patterns. For example the significant correlation (Kendal's T $=$ $0.49, \mathrm{z}=-1.99, \mathrm{p}=0.046$ ) for $301-400 \mathrm{~m}$ derives from a constant percentage of 80-85\% from 1994 to1998 and another of about 40-60\% between 1999 and 2003. Furthermore, the more linear looking trend for $51-100 \mathrm{~m}$ shows a constant $80 \%$ occurrence from 1996 to 2001 with $90 \%$ in 1994-1995 and $70 \%$ in 2002-2003. The depth is compounded with the geographic location, which exhibits almost as much variability, making it difficult to interpret interaction effects in the percentage occurrence relationship with time. All correlation coefficients were, however, negative resulting in a significant downward trend in percentage occurrence over all depths and areas from 1994 to 2003.

Figure 5 shows the percentage occurrence of $L$. depurator $\left( \pm \mathrm{CI}_{95 \%}\right.$, binomial) for depths shallower than $500 \mathrm{~m}$ in each geographic area of the Spanish coast. As with depth, no consistent annual patterns are clear except that all correlation coefficients are negative. Percentage occurrences in North Catalonia and Alicante showed significant correlations with time, but in neither case was there a good fit to a linear model (see Fig. 5). Again, interactive effects with depth undoubtedly cloud any consistent pattern but the general trend with year, across depths, is reflected by all correlation coefficients being negative even if they are not significant.

\section{Density}

Table 5 shows mean densities of $L$. depurator averaged per depth interval and geographical sector over the whole 10 years sampled. The highest den-

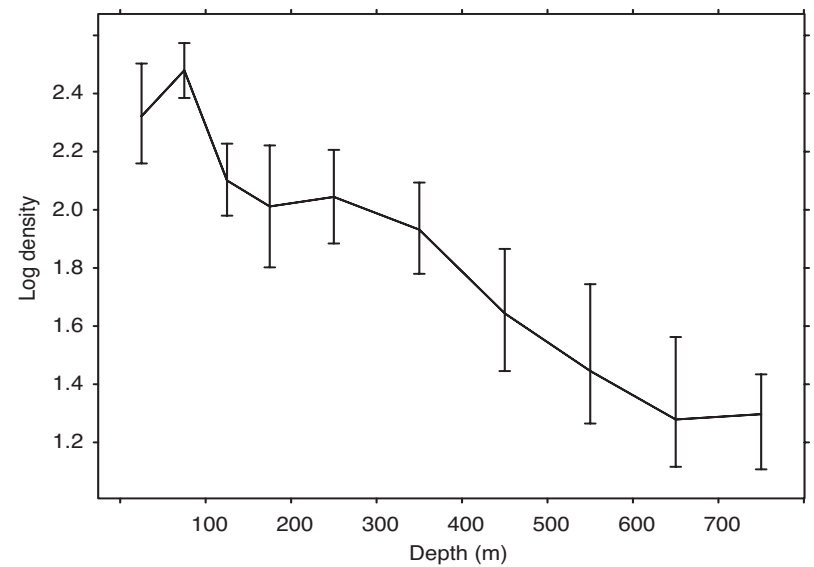

FIG. 6. - The variation in Liocarcinus depurator median density $\left(\log _{10}\right.$ (number $\left.\left.\cdot \mathrm{km}^{-2}+1\right)\right)\left( \pm \mathrm{CI}_{95 \%}\right)$ with depth along the Iberian Peninsula Mediterranean coast from 1994 to 2003.

sities occurred in the 51-100 $\mathrm{m}$ depth range for all regions except in East Alborán, where maximal densities were found between 201 and $300 \mathrm{~m}$. Maximum average densities were observed at West Alborán ( 2700 crabs $\left.\mathrm{km}^{-2}\right)$ and Valencia $(\sim 1900$ crabs $\left.\mathrm{km}^{-2}\right)$, representing an area of $370-530 \mathrm{~m}^{2}$ per crab. The frequency distribution of crab densities was heavily skewed (skeweness ranging from 2.35 in 1995 to 7.08 in 1999), thus for improved visualisation, densities were $\log _{10}$ transformed. In general, the trend in densities with depth (Fig. 6) resembled that for occurrence (Fig. 2), with crab densities generally highest in shallower depths. The second deeper peak shown for occurrences (Fig. 2) is not clearly evident for crab density (Fig. 6). From 101 to 300 $\mathrm{m}$, crab density showed little change with depth, averaging 120 to $200 \mathrm{crabs} \mathrm{km}^{-2}$. Deeper than 500 $\mathrm{m}$, densities decreased steadily to very low levels (see Fig. 6).

\section{Geographical variability}

Figure 7 shows the median $\log _{10}$ density $\left( \pm \mathrm{CI}_{95 \%}\right)$ of $L$. depurator for each geographic area combined 


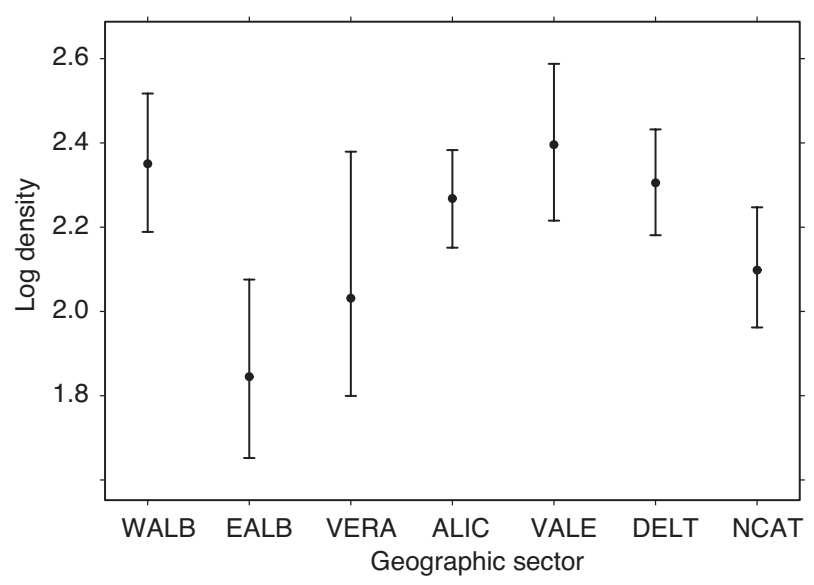

FIG. 7. - Geographic variation in Liocarcinus depurator densities (median $\log _{10}\left(\right.$ number $\left.\cdot \mathrm{km}^{-2}+1\right) \pm \mathrm{CI}_{95 \%}$ ), along the Mediterranean coast of the Iberian Peninsula from all years and depths $<500 \mathrm{~m}$.

for depth and year. The pattern closely reflects that of occurrences (see Table 3). West Alborán and Valencia showed the highest median densities, while East Alborán and the Gulf of Vera the least. Confidence intervals are large for all areas, not unsurprisingly since again, depth and year are compounded within the data.

\section{Interannual variability}

Figure 8 shows that, for the most part, the same pattern of density distribution with depth was shown throughout the years, with the highest densities evi-

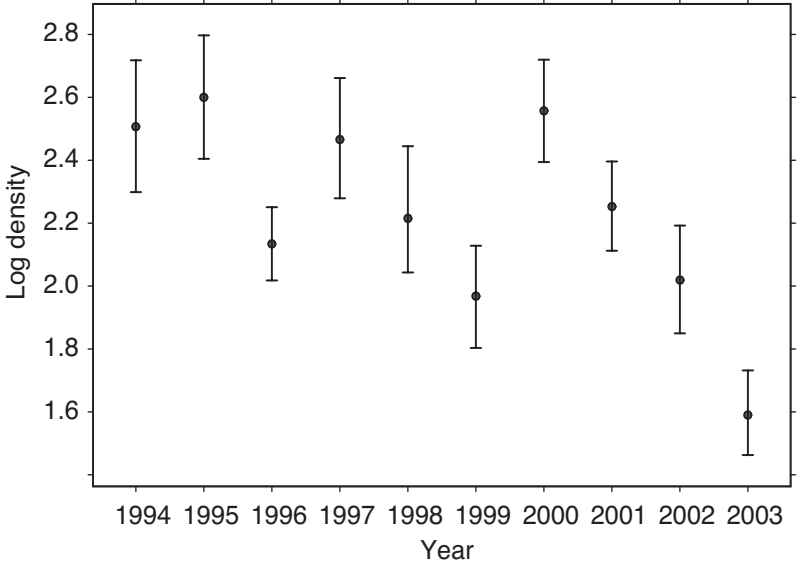

FIG. 9. - Annual variation of Liocarcinus depurator median density $\left(\log _{10}\left(\right.\right.$ number $\left.\left.\cdot \mathrm{km}^{-2}+1\right)\right)\left( \pm \mathrm{CI}_{95 \%}\right)$, along the Mediterranean coast of the Iberian Peninsula.

dent between 50-150 m. Densities then declined at greater depths. When $L$. depurator was encountered at depths between 200 and $500 \mathrm{~m}$, densities of around 50 crabs $\mathrm{km}^{-2}$ were usual and the gradual decline indicated in Figure 8 must result from increasing proportions of empty trawls. In 1996, 1999, 2003 and to a lesser degree 2001, densities appeared lower than average in the 50-150 m depth zone. The rather well defined peak, seen in other years, was much less evident and densities were much more evenly spread over the depth range. The years 1999 and 2003 were the only years showing a general density reduction, both above and below the 150-200 m contour.

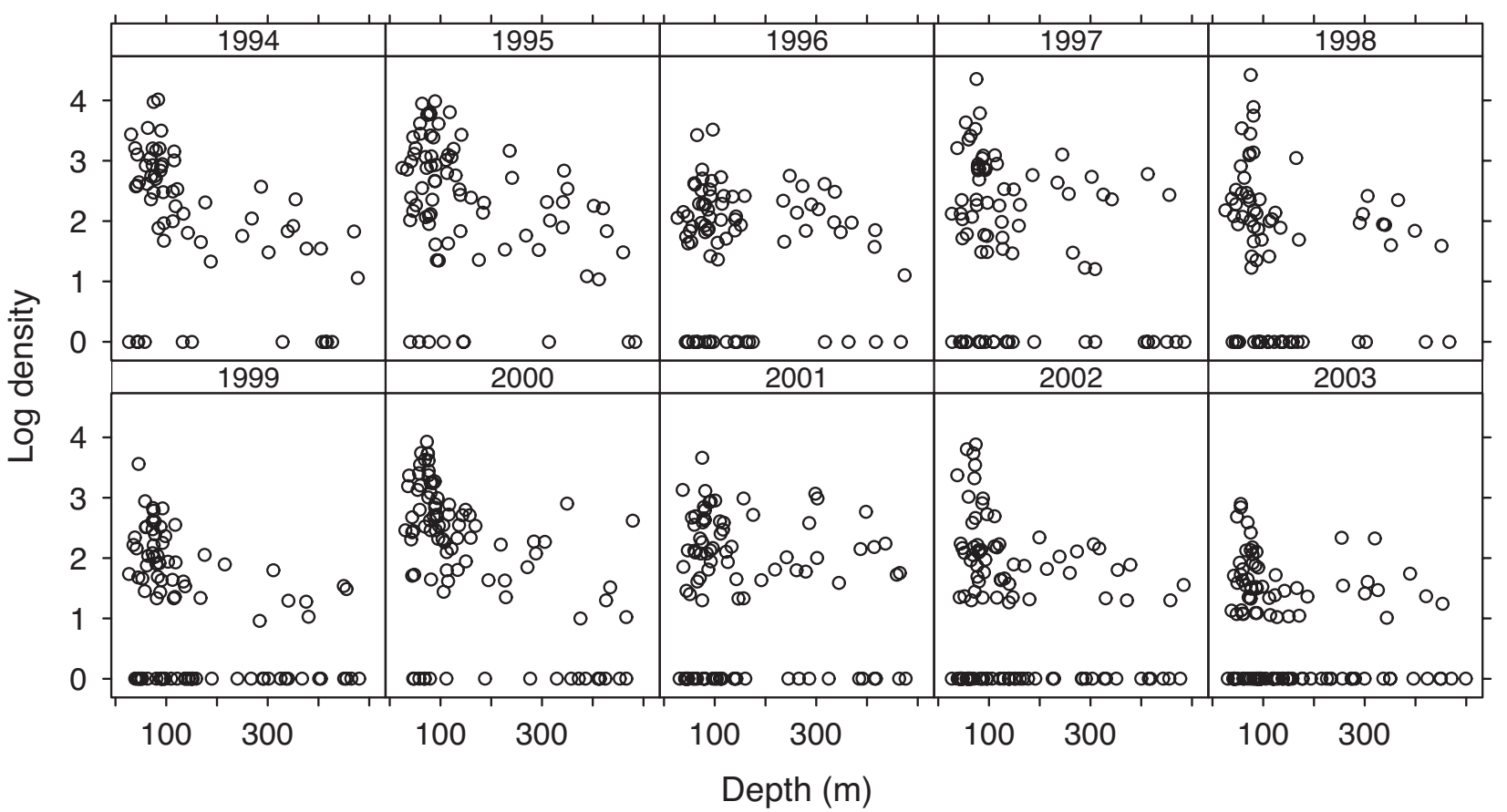

FIG. 8. - The depth distribution of Liocarcinus depurator density $\left(\log _{10}\left(\right.\right.$ number $\left.\left.\cdot \mathrm{km}^{-2}+1\right)\right)$ in each year. 


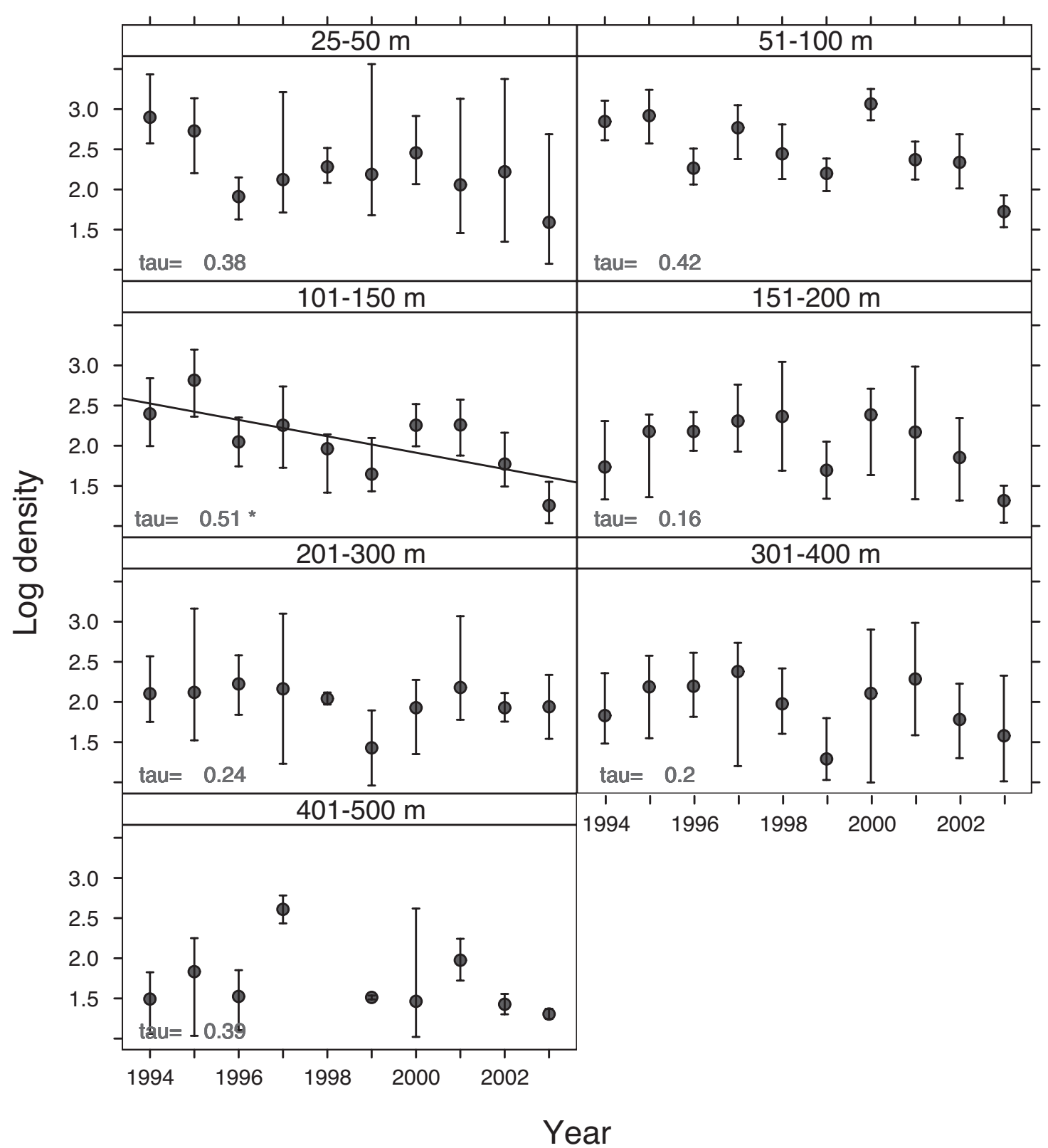

FIG. 10. - Annual variation of Liocarcinus depurator median density $\left(\log _{10}\left(\right.\right.$ crabs $\left.\left.\cdot \mathrm{km}^{-2}\right)\right)\left( \pm \mathrm{CI}_{95 \%}\right)$ at different depths (only hauls containing crabs are used). The value of Kendal's $T$ is indicated in the bottom left corner of each figure, followed by an * when significant. Lines fitted to significant relationships by least squares regression are merely indicative of the trend.

L. depurator density decreased significantly (slope $=-0.12 \log _{10}$ crabs $\mathrm{km}^{-2} \mathrm{y}^{-1}$ or a $12 \%$ annual decline in density) with year, attaining maximum average abundance in 1995 and minimum in 2003 (see Fig. 9). The patterns observed were similar to those found for crab occurrences, with a density increase followed by a greater decline from 1995 to 1999 ( 17\% annually) and from 2000 to 2003 ( $\sim 30 \%$ annually). In 1996, however, decreased density in shallower water was not accompanied by decreased occurrence (see Fig. 3).

The annual variation in crab densities (excluding hauls with no crabs present) by depth interval is shown in Figure 10. Although all correlations again indicate a decreasing trend in density with year, the only significant drop was attributable to the depth range 101-150 $\mathrm{m}$. The lowest median densities at all depths shallower than $200 \mathrm{~m}$ were evident in 2003.

Figure 11 shows that, except in West and East Alborán, the median density in 2003 was the lowest recorded since 1994, although $\mathrm{CI}_{95 \%}$ overlapped considerably (excluding hauls with no crabs present). In six out of the seven areas, a steady decline in median density is seen from 2000 to 2003, although Kendal's $\mathrm{T}$ is only significant for the decline in crab abundance in the Valencia area. East 


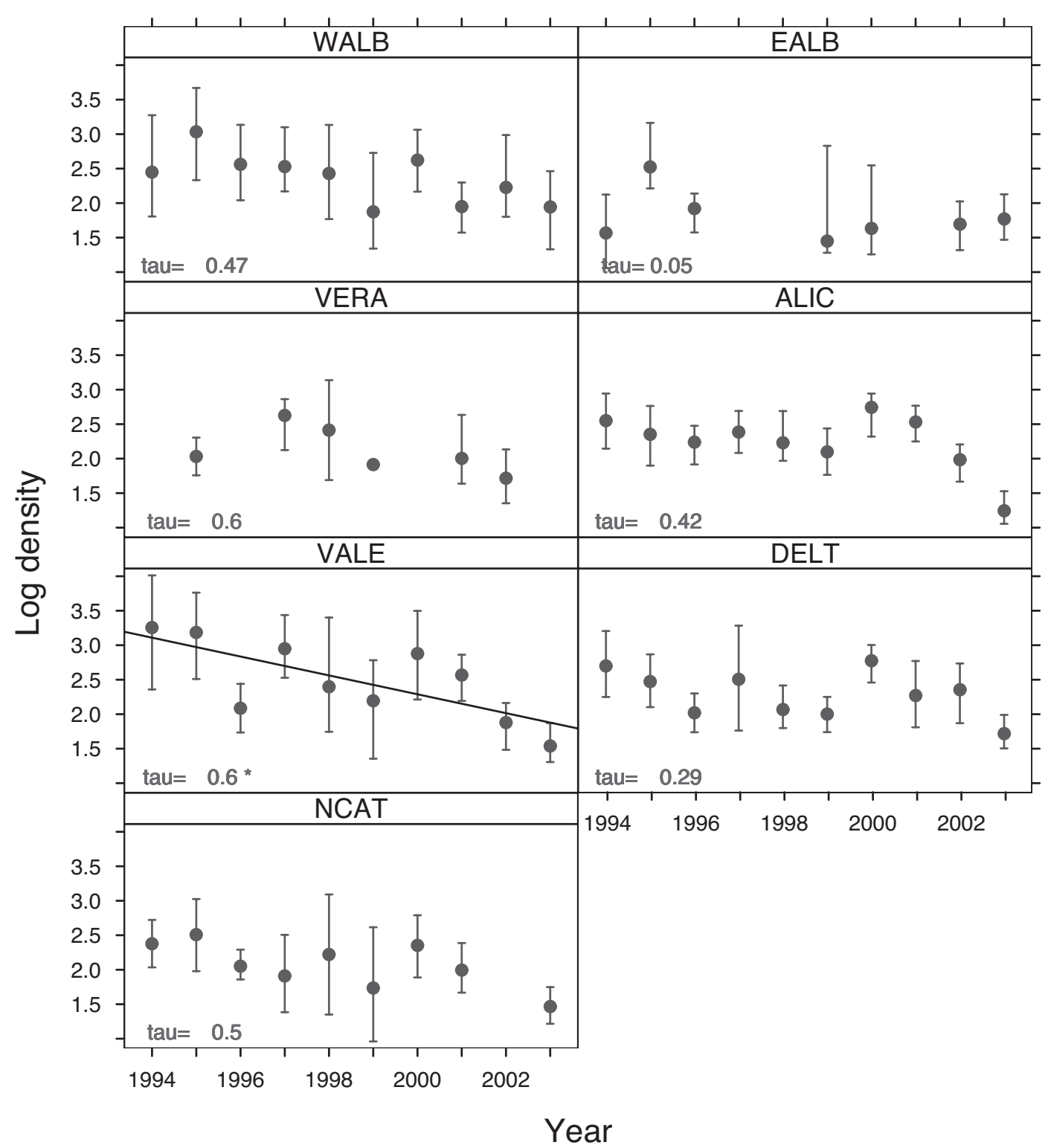

FIG. 11. - Annual variation of Liocarcinus depurator median density $\left(\log _{10}\left(\right.\right.$ number $\left.\left.\cdot \mathrm{km}^{-2}\right)\right)\left( \pm \mathrm{CI}_{95 \%}\right)$ along the Mediterranean coast of the Iberian Peninsula (only hauls containing crabs were used). The value of Kendal's $\mathrm{T}$ is indicated in the bottom left corner of each figure, followed by an * when significant. Lines fitted to significant relationships by least squares regression are merely indicative of the trend.

Alborán had the lowest crab density over the 10 years $\left(\sim 60\right.$ crabs $\left.\mathrm{km}^{-2}\right)$, whilst all other areas supported densities of $150-490$ crabs $\mathrm{km}^{-2}$ in the six years from 1994 to 2000 . Valencia supported the highest crab densities, and along with Alicante showed the most pronounced decline in median densities post 2000.

The linear model of the densities shows the relationship between depth and L. depurator $\log _{10}$ density (ignoring zero density hauls), across all geographic locations and years. There is a clear difference in the distribution of L. depurator with depth between the pattern in shallow and that in deeper waters (Fig. 12). The distribution of density has therefore been further analysed by considering the depth range $<150 \mathrm{~m}$ separately from that $>150 \mathrm{~m}$. Figure 12 also shows the fit of a 'Lowess function' to the combined densities for each area and year. Despite the widely scattered points, the fitted function indicates the existence of the modal density at around $80-90 \mathrm{~m}$. Below $150 \mathrm{~m}$ densities are fairly consistent to about $300 \mathrm{~m}$, although the Lowess fit suggests a possible density increase at around the $300 \mathrm{~m}$ mark. L. depurator densities then decline as depth increases. The two Lowess fits are suggestive of two quadratic relationships between log density and depth, potentially reflecting the two modes of occurrence evident in Figure 2. 


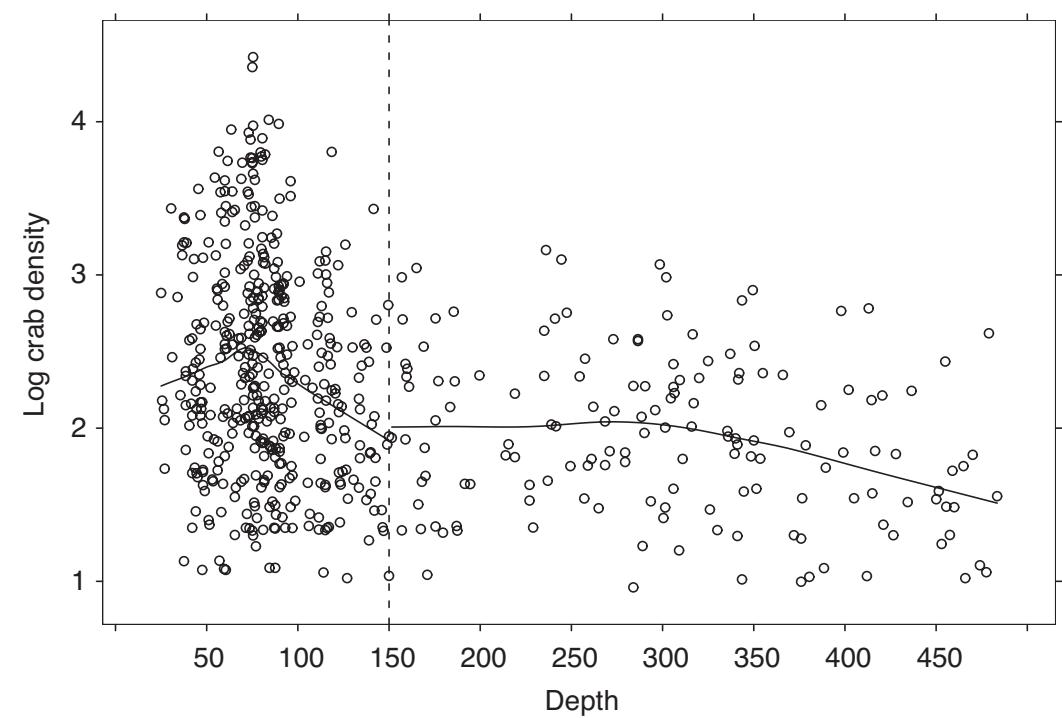

FIG. 12. - Lowess fitted to Liocarcinus depurator $\log _{10}$ densities (only positive hauls) and depth (m). One function is fitted to densities at $<150 \mathrm{~m}$ and another to those $>150 \mathrm{~m}$.
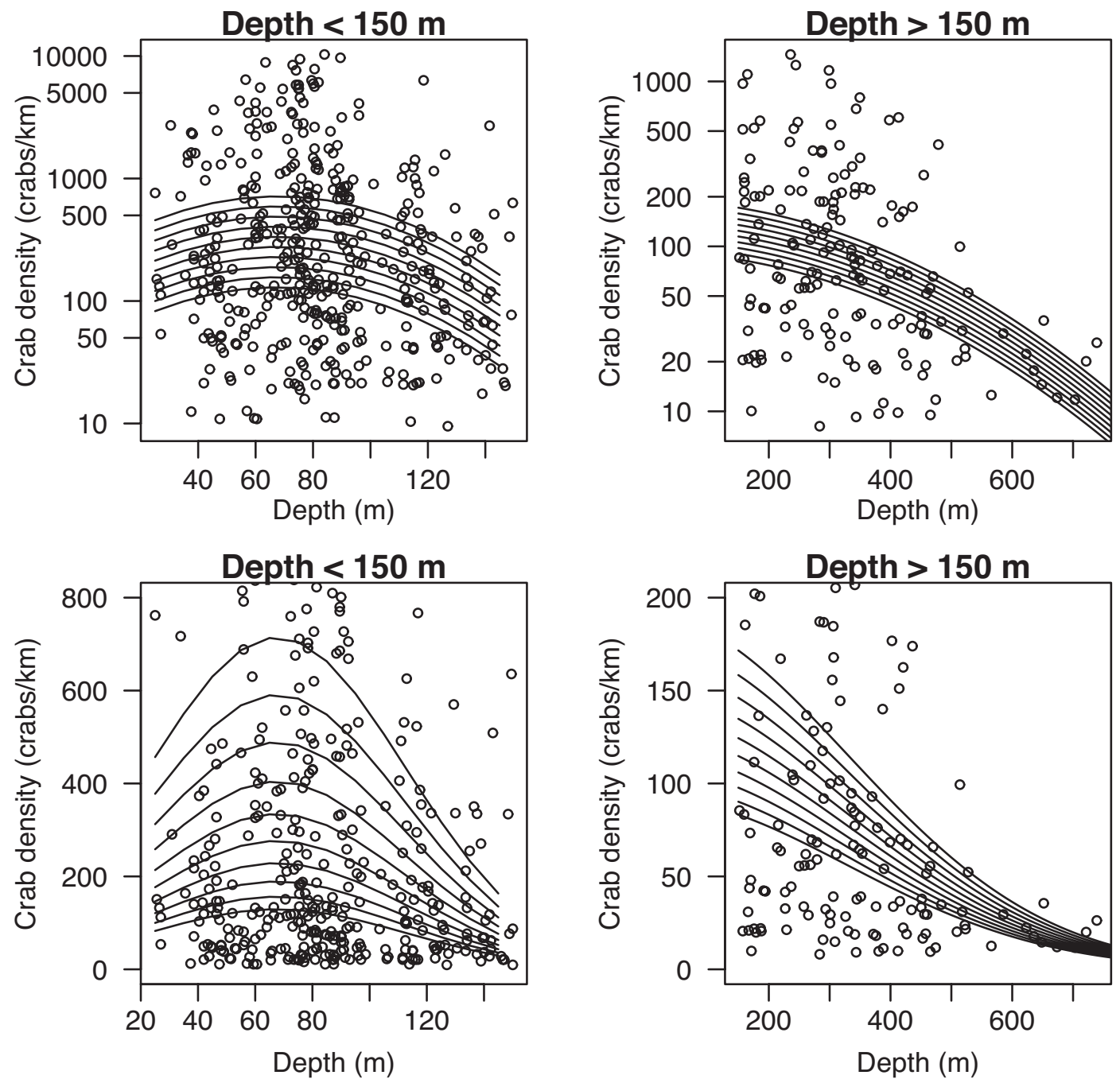

FIG. 13. - Multiple linear model for Liocarcinus depurator density (crabs km${ }^{-2} ; \log _{10}$ in a and b) and depth for all 10 years (1994 is the first line (above), 2003 the last (below)), (a) and (c) for depths shallower and (b) and (d) deeper than $150 \mathrm{~m}$. (c)-(d) detail in the density scale (the scale has been truncated at 800 and $200 \mathrm{crabs} \mathrm{km}^{-2}$ ). 
TABLE 6. - Summary of the multiple linear models fitted to the log densities of Liocarcinus depurator to year and depth.

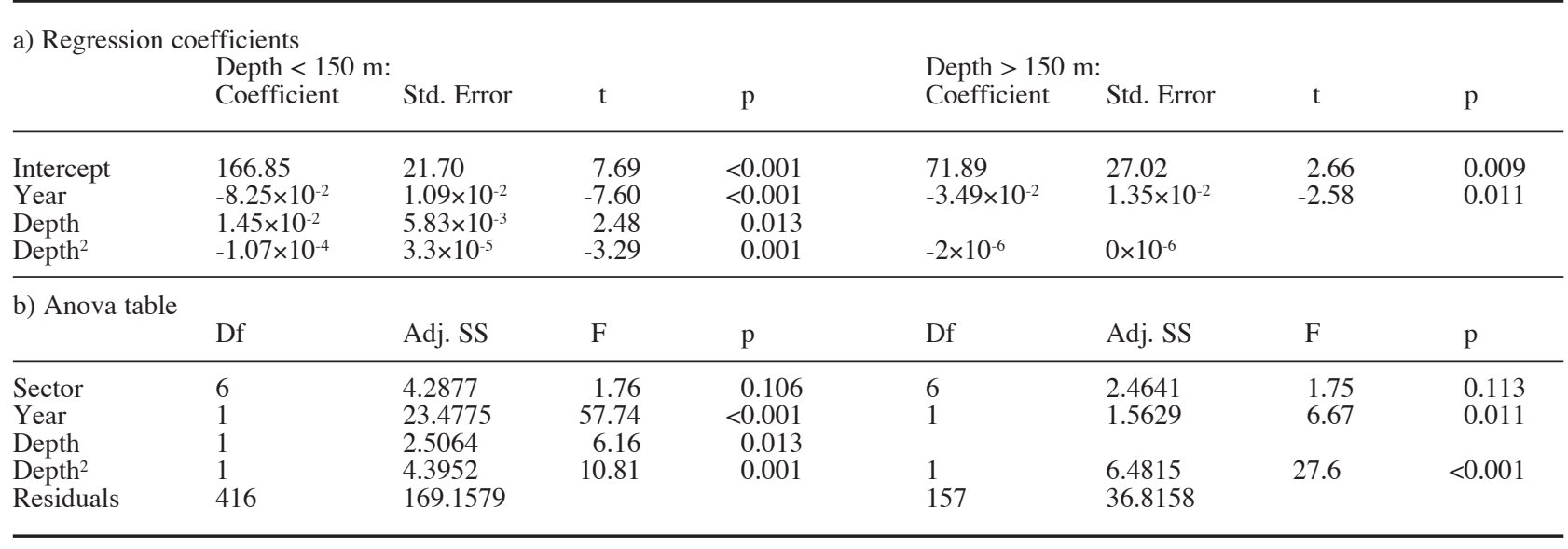

In an attempt to model changes in density with depth, year and geographic location, regression analysis was undertaken using $\log _{10}$ density as the independent variable, depth, depth squared and year as covariates and location as a fixed factor. Initial factorial analysis revealed no significant effect of location $\left(\mathrm{F}_{[1,6]}=3.01, \mathrm{p}=0.080\right)$ and no significant interaction terms ( $\mathrm{F}$ ranged from 0.79 to $1.79, \mathrm{p}$ from 0.099 to 0.574 ), hence multiple linear models were employed to express the average impact of depth and year on $L$. depurator densities. The results are shown in Figure 13a-b, where depths $<150 \mathrm{~m}$ and those greater than $150 \mathrm{~m}$ are analysed separately. The coefficient of determination for both models was low ( $<150 \mathrm{~m}: \mathrm{r}=19 \%,>150 \mathrm{~m}: \mathrm{r}=22 \%)$, yet a significant proportion of the variation was explained by the fits in each case. The spread of residuals around the fitted models indicated that a quadratic fit with depth was the most appropriate model for both data sets. The decrease of L. depurator density from 1994 to 2003 was greater at shallower depths $(\sim 8 \pm 1 \%)$ than in deeper waters $(\sim 4 \pm 1 \%)$. Figure $13 \mathrm{c}-\mathrm{d}$ shows the fit to the actual densities (no logarithmic transformation) and indicates that the peak density in shallow water is found close to $60-80 \mathrm{~m}$. The relationship with depth is modelled reasonably well ( $c f$. Lowess fit) but the representation at greater depths is less convincing $(0.2 \%$ decrease per $\mathrm{m})$.

\section{DISCUSSION}

Measurements of Liocarcinus depurator densities were obtained from a ten-year time series of bottom otter trawl surveys (1994-2003), covering a depth range of 25 to $800 \mathrm{~m}$ along the Mediterranean coast of the Iberian Peninsula (from Gibraltar to Cape Creus). The simplest approach employed divided the coast into eight areas according to geographic and geomorphic characteristics, and the depths into discrete intervals. Inference was then based on differences between median values in the light of their associated variability. This approach gave information on the overall patterns, although in most cases the high variability in the data coupled with the relatively low number of samples in some factor levels hindered interpretation.

\section{Occurrence and density}

L. depurator was present in well over half (63\%) the samples taken shallower than $400 \mathrm{~m}$, peaking at around $80 \%$ at $50-100 \mathrm{~m}$. The percentage occurrence decreased sharply to average $15 \%$ of hauls taken deeper than $400 \mathrm{~m}$. Densities also peaked at 50-100 m, but decreased steadily with depth, especially below $400 \mathrm{~m}$. On average $L$. depurator distribution and abundance appeared to be delineated by depth such that the highest abundance occurred in the shallower samples (51-150 m depth strata). Density was fairly constant down to about 301-400 m although crab occurrence exhibited a second potential mode at around 301-400 m. L. depurator was increasingly scarce below $500 \mathrm{~m}$ and virtually absent below $700 \mathrm{~m}$. A similar distribution has been noted in the western Mediterranean (Abelló et al., 2002), but never observed in such detail over an area as large as the current study. Since depth (and related factors) constitutes such a limiting element for $L$. depurator, by combining the results from a wide geographic area over ten years, the distribution of the crab with depth 
was relatively clear despite the wide variation in density measurements obtained.

However, with the strong effects of year and depth compounded in the median estimates of density for geographic locations, resulting in very high confidence intervals, any detailed difference between areas was not significant. The delineation of the areas for comparisons within the study was at best convenient and at worst arbitrary. Any conclusions drawn from differences between crabs in particular areas must clearly depend on the characterisation of the areas. There are various generalisations that characterise certain areas (wide continental shelf, steep shelf slope, muddy substrata, etc.) and they were chosen specifically due to these characteristics. However, the size of the areas and their latitudinal or longitudinal extent reflects mostly a convenient apportionment of the coastline. It is little wonder, then, when attempts to consider crab density distribution differences in relation to depth and year between areas flounder in a sea of variability. The simple approach is thus fraught with difficulty because of the inability to define the variability precisely (arbitrary geographic areas) or the variable of interest becomes discrete rather than continuous (depth intervals as opposed to actual depth), which inevitably leads to a loss of variability when group means are examined. Furthermore, the inevitable interaction effects derived make it impossible to interpret the effect of each factor separately.

A more sophisticated approach is to attempt modelling, on a continuous scale, to estimate variability associated with measured influences and attempt to ascribe probability levels to the effects or differences. In this approach, depth was considered as a continuous variable, which is certainly more realistic than dividing it into intervals. However, the study area stretched from north-east to southwest, making latitude and longitude unhelpful continuous variables to model, hence geography still had to be interpreted through discrete areas. The densities of $L$. depurator were thus subjected to analysis through linear modelling but with limited success, highlighted by the low percentage of explained variance. The generalities of distribution with depth were reasonably well approximated by linear and quadratic terms in depth but only when the depth distribution was split in two, either side of $150 \mathrm{~m}$ depth. Maximum L. depurator densities were estimated to be located around 70-80 m, similar to that found off Málaga (García-Raso, 1984, maximum densities between 36 and $90 \mathrm{~m}$ ), in the
Ligurian Sea (Mori and Zunino, 1987, maximum densities at $90 \mathrm{~m}$ ), in the Catalan Sea (Abelló, 1986; Abelló et al., 2002, maximum densities between 50 and $100 \mathrm{~m}$ ) and off Cyprus (Lewinsohn and Holthuis, 1986, from 73 to $110 \mathrm{~m}$ ).

L. depurator densities tended to be highest in the areas where the continental shelf was wider. Areas like East Alborán and the Gulf of Vera which have poorly delimited continental shelves and particularly steep slopes, with little muddy substrata, had the lowest crab densities. The continental shelf from Castelló - Columbretes islands to the Ebro Delta is the widest along the Mediterranean coast of the Iberian Peninsula and also receives the outflow of silt and clay from the river Ebro. This area is highly productive, boosted by the input from the river, particularly to the south and southwest where nutrients from the river are carried by the prevailing currents (Estrada, 1996; Salat, 1996). L. depurator exhibited moderate densities off North Catalonia but also decreased sharply in occurrence post 2000. Additionally, L. depurator was virtually absent from the waters around Ibiza, an area with oligotrophic oceanic characteristics with a strong influence from Atlantic waters (Hopkins, 1985; García-Lafuente et al., 1995; Salat, 1995), and very low river runoff (Canals and Serra, 1992), which determines the sediment characteristics (Emelyanov, 1972).

L. depurator is thus abundant on the continental shelf and upper slope, but appears less common along the shelf break. The shelf break in the study area occurs at around $150 \mathrm{~m}$ (Díaz et al., 1990), and the sediment consists in a mixture of gravel with some sand, silt and many remnants from benthic organisms (dead and subfossil), rather than the terrigenous muds characteristic of the shelf (Blake and Doyle, 1983; Díaz et al., 1990). In deeper waters along the upper and middle continental slope, muddy sediments again constitute the most widespread type of sediment (Blake and Doyle, 1983). In this context, $L$. depurator appears to clearly favour muddy sediments over sandy or coarser sediments normally associated with higher water current velocities (Minervini et al., 1982; Rufino et al., 2004). Similar patterns of bimodal depth distribution associated with sediments with different proportions of coarse particles are found in the study areas for the distributions of burying and burrowing decapod crustaceans, such as the crabs Goneplax rhomboides, Medorippe lanata, Calappa granulata and Monodaeus couchi, the Norway lobster Nephrops norvegicus and the hermit crabs Dardanus 
arrosor and Pagurus prideaux (Abelló et al., 1988; Abelló et al., 2002).

\section{Interannual variability}

Interannual variability in $L$. depurator density presented a less straightforward interpretation since at least two trends were present and the variation with depth appeared to differ between years with little apparent pattern, thus increasing variances. Over the ten-year period, a general downward significant trend, both in crab occurrence and density, was apparent. Potentially superimposed, however, was what appeared to be a cyclical trend in abundance with an approximate periodicity of 3 to 4 years. Cycles of low and high population abundance have been shown for several species but not previously for $L$. depurator in the western Mediterranean. If $L$. depurator had a maximum life span of 3 to 4 years, the potential periodicity of the population abundance would fit perfectly. There are, however, few growth or life-span studies on $L$. depurator, either in the Mediterranean or in the Atlantic. From size frequency analysis of a western Mediterranean upper-slope population in one year, Abelló (1986) observed that the population was basically structured on 4 to 5 main modal sizes which could correspond to the age structure of the population. Growth data on the Ebro delta continental shelf population, estimated from size frequency distributions is, however, suggestive of a maximum life-span of around 2 years (Abelló, unpublished), which makes the population highly recruitment dependent. Fernández et al. (1991) estimated a shorter life-span of around 18 months for the L. depurator population in the Atlantic Galician rias. Thus, the potential cycle may well be driven by the occasional high recruitment in certain years followed by a steady decline in population numbers as that year class dies out. Occurrence (potential habitat occupancy) of $L$. depurator followed a very similar cycle, which indicates greater habitat occupancy when densities are highest.

The multiple linear analysis clearly established the prevailing trends. It ascribed statistical significance to the trends and partitioned the effect of each variable within the total variance, both separately and in combination. The basic assumptions of parametric analysis, however, are often difficult to meet with biological data. Methods such as generalised additive models may overcome such assumptions and linearity, but inference and interpreting the results can become difficult (Quinn and Keough, 2002).
Density of $L$. depurator decreased significantly from 1994 to 2003, but at a greater rate of decline ( $8 \%$ per annum) in shallower water on the continental shelf $(<150 \mathrm{~m})$, where crab densities were greater. The strongest decreases seen tended to be in the 101-150 $\mathrm{m}$ range, where high densities were generally absent post 2000 . The lowest densities by far were found in 2003. The currently recorded decrease in occurrences and densities of L. depurator may be put into the context of the so-called faunistic 'tropicalisation' observed during the last few decades, particularly the last 10-15 years (Bianchi and Morri, 1993; Francour et al., 1994; Riera et al., 1997). It has been suggested that this phenomenon is a consequence of the potential global increase in the Earth's temperature (Peñuelas and Filella, 2001). Temperature increases have also been observed in Mediterranean Sea waters (Bethoux et al., 1990; Pascual et al., 1997; Salat and Pascual, 2002). Climatically driven ecosystem disturbance has also been recently reported in coastal areas of the western Mediterranean, where the anomalous increase of summer temperatures and the deepening of the thermocline have resulted in massive mortalities of sessile organisms on hard benthic substrata (Coma et $a l ., 2000)$. Mortality was attributed not only to the water warming per se, which may affect the physiology of the individuals and their tolerance limits to environmental variations, but also to the stability of high sea temperatures over long periods, with the consequent stratification and depletion of nutrients.

Recruitment is the main determinant of population density in short-lived abundant species, such as L. depurator (Mori and Zunino 1987, Abelló 1989, Fernández et al. 1991). The only previous study on a temporal series of catches of L. depurator is restricted to that of Lloret et al. (2001), who found an increase in catches and CPUE for the short time series (1990-1994) available for L. depurator from two harbours in the south-west Gulf of Lions. This time series ended precisely with relatively high density levels when our time series started in 1994. This could correspond to the high levels observed at the start of our time series and be part of a large overall cycle. A significant effect of wind mixing and river discharges on catches/recruitment of L. depurator in the north-western Mediterranean was found by Lloret et al. (2001), among other species. Lags of six to eight months were recorded between catch/CPUE (catch per unit effort) and wind mixing and river flow. A strong seasonality of catches, attributed to recruitment to the fishery, was also recorded. 
Tolerance limits (to temperature among other things) set limits to the distribution of an organism. L. depurator is a species whose overall geographical distribution (from Morocco to Norway) is centred along the temperate eastern Atlantic seaboard with the Mediterranean representing its highest temperature range, presumably closer to its upper tolerance limit. Hence, the recorded increase in water temperature in different areas of the Mediterranean in the last years (Bethoux et al., 1990; Pascual et al., 1997; Salat and Pascual, 2002), may be having an adverse effect on its physiology, survival and/or recruitment success. Wear (1974) noted that larval viability of British decapod crustaceans (L. depurator among them) was reduced when egg development took place at temperatures outside the normal springsummer range $\left(8-16^{\circ} \mathrm{C}\right)$. Indeed, viability was particularly decreased when eggs were incubated at higher than normal temperatures. Slight increases in water temperature of up to $3^{\circ} \mathrm{C}$ could reduce fecundity by more than $90 \%$. Thus, as a temperate-cold water species, any influence of global temperature increase on L. depurator should be felt earlier in the Mediterranean than in the more northerly parts of its distribution. In fact, the peak of reproduction (egg and larval development) of $L$. depurator in the Mediterranean takes place in winter, during the coldest months (Mori and Zunino, 1987; Abelló, 1989). This could be a reason why occurrence seems to have declined more quickly in the north of the study area (Fig. 1) than in the south, where colder Atlantic water has more influence.

\section{ACKNOWLEDGEMENTS}

The authors wish to thank all participants in the MEDITS-ES cruises, particularly their chief scientist Dr. L. Gil de Sola and A. Carbonell for all help and collaboration provided. This work was inserted in the MMR $\mathrm{PhD}$ program financed by Fundação para a Ciência e a Tecnologia BD /21569 / 99.

\section{REFERENCES}

Abelló, P. - 1986. Anàlisi de les poblacions de crustacis decàpodes demersals al litoral catalá: aspectes biològics del braquiür Liocarcinus depurator. Ph.D. Thesis, Universitat de Barcelona.

Abelló, P. - 1989. Reproduction and moulting in Liocarcinus depurator (Linnaeus, 1758) (Brachyura: Portunidae) in the northwestern Mediterranean Sea. Sci. Mar., 53: 127-134.

Abelló, P. and J.E. Cartes. - 1987. Observaciones sobre la alimentación de Liocarcinus depurator (L.) (Brachyura: Portunidae) en el Mar Catalán. Inv. Pesq., 51 (Suppl. 1): 413-419.
Abelló, P., F.J. Valladares and A. Castellón. - 1988. Analysis of the structure of decapod crustacean assemblages off the Catalan coast (North-West Mediterranean). Mar. Biol., 98: 39-49.

Abelló, P., A. Carbonell and P. Torres. - 2002. Biogeography of epibenthic crustaceans on the shelf and upper slope off the Iberian Peninsula Mediterranean coasts: implications for the establishment of natural management areas. Sci. Mar., 66 (Suppl. 2): 183-198.

Beare, D.J., F. Burns, A. Greig, E.G. Jones, K. Peach, M. Kienzle, E. McKenzie and D.G. Reid. - 2004. Long-term increases in prevalence of North Sea fishes having southern biogeographic affinities. Mar. Ecol. Prog. Ser., 284: 269-278.

Beare, D.J., F. Burns, E. Jones, K. Peach and D. Reid. - 2005. Red mullet migration into the northern North Sea during late winter. J. Sea Res., 53: 205-212.

Bertrand, J., L. Gil de Sola, C. Papaconstantinou, G. Relini and A. Souplet. - 2000. Distribution of juveniles of some demersal species in the northern Mediterranean. Biol. Mar. Medit., 7: 81-97.

Bertrand, J., L. Gil de Sola, C. Papaconstantinou, G. Relini and A. Souplet. - 2002. The general specifications of the MEDITS surveys. Sci. Mar., 66 (Suppl. 2): 9-17.

Bethoux, J.P., B. Gentili, J. Traunet and D. Tailliez. - 1990. Warming trend in the western Mediterranean deep water. Nature, 347: 660-662.

Bianchi, C.N. and C. Morri. - 1993. Range extensions of warmwater species in the northern Mediterranean: evidence for climatic fluctuations? Porcupine Newsletter, 5: 156-159.

Blake, N.J. and L.J. Doyle. - 1983. Infaunal-sediment relationships at the shelf-slope break. Soc. Econom. Paleontolog. Mineralog. Spec. Publ., 33: 381-389.

Canals, M. and J. Serra. - 1992. Morfologia submarina i litoral. In: R. Folch (Ed), Història Natural dels Països Catalans. 2. Geologia II, pp. 390-438. Enciclopèdia Catalana, Barcelona.

Coma, R., M. Ribes, J.M. Gili and M. Zabala. - 2000. Seasonality in coastal benthic ecosystems. Trends Ecol. Evol., 15: 448-453.

Díaz, J.I., C.H. Nelson, J.B. Barber and S. Giró.- 1990. Late Pleistocene and Holocene sedimentary facies on the Ebro contiental shelf. Mar. Geol., 95: 333-352.

d'Udekem d'Acoz, C. - 1999. Inventaire et distribution des crustacés décapodes de l'Atlantique nort-oriental, de la Méditerranée et des eaux continentales adjacentes au nord de $25^{\circ} \mathrm{N}$. Collection Patrimoines Naturels vol. 40. SPN / IEGB / MNHN, Paris.

Emelyanov, E.M. - 1972. Principal types of recent bottom sediments in the Mediterranean Sea: their mineralogy and geochemistry. In: D.J. Stanley (ed.), The Mediterranean Sea: a natural sedimentation laboratory, pp. 355-386. Dowden, Stroudsburg.

Estrada, M. - 1996. Primary production in the northwestern Mediterranean. Sci. Mar., 60 (Suppl. 2): 55-64.

Fernández, L., E. González-Gurriarán and J. Freire. - 1991. Population biology of Liocarcinus depurator (Brachyura: Portunidae) in mussel raft culture areas in the Ria de Arousa (Galicia, NW Spain). J. mar. biol. Ass. U.K., 71: 375-390.

Fiorentini, L., P.-Y. Dremière, I. Leonori, A. Sala and V. Palumbo. - 1999. Efficiency of the bottom trawl used for the Mediterranean international trawl survey (MEDITS). Aquat. Living Resour., 12: 187-205.

Francour, P., J. Boudouresque, G. Harmelin, M.L. Harmelin-Vivien and J.P. Quignard. - 1994. Are the Mediterranean waters becoming warmer? Information from biological indicators. Mar. Pollut. Bull., 28: 523-526.

Freire, J. - 1996. Feeding ecology of Liocarcinus depurator (Decapoda: Portunidae) in the Ria de Arousa (Galicia, northwest Spain): Effects of habitat, season and life history. Mar. Biol., 126: 297-311.

García-Lafuente, J.M., J.L. López-Jurado, N. Cano, M. Vargas and J. Aguiar. - 1995. Circulation of water masses through the Ibiza Channel. Oceanol. Acta, 18: 245-254.

García-Raso, J.E. - 1984. Brachyura of the coast of Southern Spain (Crustacea, Decapoda). Spixiana, 7: 105-113.

González-Gurriarán, E., J. Freire and L. Fernández. - 1993. Geostatistical analysis of spatial distribution of Liocarcinus depurator, Macropipus tuberculatus and Polybius henslowii (Crustacea: Brachyura) over the Galician continental shelf (NW Spain). Mar. Biol., 115: 453-461.

Hall, S.J., D. Raffaelli, M.R. Robertson and D.J. Basford. - 1990. The role of the predatory crab, Liocarcinus depurator, in a marine food web. J. Anim. Ecol., 59: 421-438. 
Hopkins, T.S. - 1985. Physics of the sea. In: R. Margalef (ed.), Key Environments: Western Mediterranean, pp. 100-125. Pergamon Press, New York.

Lewinsohn, C. and L.B. Holthuis. - 1986. The Crustacea Decapoda of Cyprus. Zool. Verh., 230: 1-64.

Lloret, J., J. Lleonart, I. Solé and J.-M. Fromentin. - 2001. Fluctuations of landings and environmental conditions in the northwestern Mediterranean Sea. Fish. Oceanogr., 10(1): 33-50.

Minervini, R., M. Giannotta and L. Falciai. - 1982. A preliminary report on the decapod crustaceans in the estuarine area of the Tiber. Quad. Lab. Tecnol. Pesca., 3 (2-5): 305-318.

Mori, M. and R. Manconi. - 1989. Alimentazione di Liocarcinus depurator (L.) (Crustacea: Decapoda) in Mar Ligure. Boll. Mus. Ist. Biol. Univ. Genova, 53: 69-79.

Mori, M. and P. Zunino. - 1987. Aspects of the biology of Liocarcinus depurator (L.) in the Ligurian Sea. Inv. Pesq., 51 (Suppl. 1): 135-145.

Pascual, J., J. Salat and M. Palau. - 1997. Evolución de la temperatura del mar entre 1973 y 1994, cerca de la costa catalana. In: $L a$ Méditerranée: variabilités climatiques, environnement et biodiversité, pp. 23-28. Maison de l'Environnement, Montpellier.

Peñuelas, J. and I. Filella. - 2001. Responses to a warming world. Science, 294: 793-795.

Quinn, G.P. and M.J. Keough. - 2002. Experimental design and data analysis for biologists. Cambridge University Press, Cambridge.

Riera, F., A.M. Grau, E. Pastor and S. Pou. - 1997. Faunistical and demographical observations in Balearic ichthyofauna. Meridionalization or subtropicalization phenomena. In: La Méditér- ranée: variabilités climatiques, environnement et biodiversité, pp. 213-220. Maison de l'Environnement, Montpellier.

Rufino, M.M., F. Maynou, P. Abelló and A.B. Yule. - 2004. Smallscale non-linear geostatistical analysis of Liocarcinus depurator (Crustacea: Brachyura) abundance and size structure in a western Mediterranean population. Mar. Ecol. Prog. Ser., 276: 223-235.

Salat, J. - 1995. The interaction between the Catalan and Balearic currents in the southern Catalan Sea. Oceanol. Acta., 18: 227-234.

Salat, J. - 1996. Review of hydrographic environmental factors that may influence anchovy habitats in northwestern Mediterranean. Sci. Mar., 60 (Suppl. 2): 21-32.

Salat, J. and J. Pascual. - 2002. The oceanographic and meteorological station at L'Estartit (NW Mediterranean). CIESM Workshop Series, 16: 29-32.

Ungaro, N., G. Marano, A. Vlora and G. Passarella. - 1999. Distribution patterns of two species of swimming crabs (Portunidae), Liocarcinus depurator (L.) and Macropipus tuberculatus (Roux), in the southwestern Adriatic Sea (Mediterranean Sea). In: J.C. Von Paupel-Klein and F.R. Schram (eds.), The Biodiversity Crisis and Crustacea: Proceedings of the Fourth International Crustacean Congress, Amsterdam, The Netherlands, July 20-24, 1998, pp. 131-138. A.A. Balkema, Rotterdam.

Wear, R.G. - 1974. Incubation in British Decapod Crustacea, and effects of temperature on rate and success of embryonic development. J. mar. biol. Ass. U.K., 54: 745-762.

Scient. ed.: C. Zeng 